\title{
The Research of The Strategies of Improving The Culture Level of Peasant Household Tourism Products
}

\author{
Zhang Yan \\ (Environmental Management College of China, Department of ecology ,Qinhuangdao 066102, \\ China)
}

Keywords: Peasant household tourism, cultural level, cultural connotation

\begin{abstract}
In recent years, rural tourism products which are focusing on farm house enjoyment is developing fast in many places of China. However, problems exist at the same time. There are lots of problems in peasant household tourism development, and the basic one is its shallow cultural connotations and low cultural tastes. Therefore, peasant household tourism must pay attention to enrich the cultural connotation and improve the cultural taste to maintain its enduring attractiveness and strong vitality, and to realize the sustainable development.

Peasant household tourism, one form of the rural tourism, is popular at the suburb of Chengdu since 1990s. it has been developing for more than twenty years in China. In the process, peasant household tourism meet the needs of citizens in modern cities, to return to the basics and back to nature. It improves the structure of China' $s$ tourism products and has become the splash of the increase of China' s tourism economy. However, as farm house enjoyment is developing, problems appear.

This situation has arisen the attention among academic circles, and a lot of scholars analyze the problems which are existed in the development of peasant household tourism. At present, peasant household tourism has problems such as blind construction, lack of characteristics, single form and low tastes. On one hand, it is unable to meet the growing diversified demand of tourists. On the other hand, it lacks of stamina for sustainable development and is difficult to maintain long term attractiveness and vitality.

Among the deficiencies and problems of the peasant household tourism, the lack of cultural taste is not only the fundamental flaw, but also the root cause of the low quality of peasant household tourism products. Hence, we are supposed to focus on problems such as how to enrich the cultural connotation of the peasant household tourism and how to improve the cultural taste.
\end{abstract}

\section{The main features of peasant household tourism' s lacking of cultural level}

\section{The blindly construction destruct the rural resources and environment}

Rural resources and environment is the reliance and base of the development of peasant household tourism. Any damage to the development and construction of the peasant household tourism will weaken its attractiveness and reduce its cultural tastes. However, situations as ignoring the actual conditions to develop some resources and then result in the increasing of ecological pressure, exist in the development of the peasant household tourism.

At the same time, due to the deviation of the farmers in understanding, the construction of the tenement and courtyard blindly imitate buildings in cites. This kind of farm house enjoyment not only lose its rural character, but also destruct local resources and environment. What' s more, the inappropriate deal of the rubbish and waste water which are produced in the development of peasant household tourism result in the degeneration of rural ecological environment. The destruction of rural resources and environment will cause the lost of the ecological advantages of peasant household tourism, the reduction of rural attractiveness, the decline of the cultural tastes of farm house enjoyment, and will affect the sustainable development of peasant household tourism.

\section{The excavation of rural culture is not enough}

So far, the development of peasant household tourism products cannot make full use of rural cultural connotations. 
Firstly, sided emphasize the development of rural natural resources and neglect the use of local culture and rural folk culture. Even some peasant household tourism are engaged in increasing cultural content, but they all copy from each other instead of according to local customs and traditions, which result in the lack of characteristics.

Secondly, activities of the farm house enjoyment are with low level, lack of cultural contents and characteristics. The activities are mainly chess and mahjong, auxiliary by activities such as drinking tea, chatting and fishing. The development of the project lacks of characteristics, sense of urbanization and popularity is strong, tourists' needs such as innovation, divergent and knowledge cannot be met.

Thirdly, the development of farm house enjoyment does not have a close contact with farming culture, the excavation of farming culture is not enough, and lack of tangible demonstration. Fewer rural characteristics are embodied in peasant household tourism.

\section{The form is mainly sightseeing, lack of participation}

Nowadays, the development of peasant household tourism still stays on the level of sightseeing, with single product structure and poor informative and interesting, and the participation is not strong. Sightseeing agriculture week of most of peasant household tourism can satisfy the needs of tourists to enjoy the bucolic.

However, due to the lack of participation, tourists can only stay for a short time and the process is dull. Tourists are increasingly focused on the participation and experience in the process of tourism, but tourists experience requirements cannot be satisfied by this kind of tourism products. Though rural folk culture can better develop some tourism projects, which are participatory and experiential, most of the peasant household tourism does not have tourism projects with strong participation, such as folk festivals and folk arts learning.

\section{Bad service facilities and low service level}

The service of peasant household tourism is a platform to show the cultural tastes of farm house enjoyment. Good service facilities and service level can not only delight tourists, but also establish a good image of peasant household tourism among tourists. However, at present, service facilities of peasant household tourism is not good, and the service level still needs to be enhanced. The construction of service facilities usually cannot coordinate with rural environment. The safety and sanitary condition of service facilities is still not good enough. The sanitary condition of the kitchen and tableware is bad. Foods provided here is not much different from that of cities and lack of features of rustic food culture.

At the same time, the manager of farm house enjoyment is still lack of the cognition that

"service is taste" , they also lack of humane care for tourists. The deportment and way of service cannot make tourists feel delighted. All these conditions decline the cultural taste of peasant household tourism.

\section{The importance of enhancing the cultural level of agricultural tourism}

\section{In line with the development trend of China' s agricultural tourism}

With the development of the times, we are now in a era of protacting ecological environment, returning to nature and backing to the trditional post-industrial civilizaition. People' s consumption concept is changing from the pursuit of material consumption to the pursuit of customer experience. Under this socio-economic background, people' $s$ focus on industry development is changing from the promotion within the industry to the mutual promotion between industries.

This change is good for breaking the boundary between agriculture and tourism, and realize the merging of the two industries. While the condition of the merge is cultural infiltration. Only based on the cultural infiltration and the enhance of cultural tastes can there be a mature modern agri-tourism industry. In agricultural tourism activities, resourse is the base, and culture is the soul. The biggest economical, ecological and social benefits of agricultural tourism is that it can furthest excavate the profound cultural details. 
Agricultural tourism is a high-level cultural tourism. It needs to meet the needs of high-level culture. The culture of agricultural tourism is unique. People get know of rural lifestyle, national characteristics, local characteristics and experience the high-tech agriculture by way of travel. Based on these, tourists can feel the local agricultural culture more convenient and realize the pursuit of cultural differences or cultural identity, to achieve the goal of aesthetic and self-improvement.

Therefore, it is the motivation of the sustainable development of agricultural tourism that concentrating on the exploration and refining of farming cultural connotation in China's places with abundant agricultural regional resources and prominent features.

\section{Good for promoting the construction of new socialist countryside}

As the new format with the combination of primary industry and tertiary industry, agricultural tourism, which is based on the increase of ways of developing cultural tastes, plays an important part in promoting economy development. On basis of taking full advantage of the unique cultural resources of local tourism, agricultural tourism is promoting the common devlopment of the secondary industry and tertiary industry in aspects of food, shelter, transportation, travel, shopping and entertainment. It also has a positive impact on promoting the construction of social economy, investment environment, infrastructure, job market and agricultural products and so on.

At the same time, it is benefitial to the change of the structure of traditional agricultural industry, the improvement of the ability of value creation, and the change of the weak form of the development of agricultural industry.

Hence, developing agricultural tourism plays an important role in promoting the reform and development of the countryside, pacing urban and rural arrangement and constructing new socialist countryside. It is an effective way to solve the three dimentional rural issues, lead farmers to get rich and promote the rural modernization. It is also a positive exploration of breaking urban-rural dual structure and realizing the urban-rural integration. Only the tourism culture maintain its own distinctive characteristics and unique style can it be invincible in the international and domestic competition, and make sure the harmonious and sustainable development of a new socialist countryside.

\section{Good for the improvement of people' s science and culture quality}

As a cultural phenomenon and a cultural consumption, it is the cultural and spiritual products that tourism purchased. In the process of tourism, people can enjoy themselves and improve the quality of spiritual life. Agricultural tourism lays stress on participation. Tourists are not satisfied with the general formula cursory viewing, what they really want is the travel deep into human environment in the countryside to experience the interesting farming culture.

Both natural landscapes and human landscapes are the carrier of agricultural tourism and the window to demonstrate scientific culture. Tourists can not only enjoy the natural scenery, historical site and local custom, but also get the knowledge history, culture, national traditions, literature, art and scientific, which can broaden their horizons, cultivate their tastes and get educated.

At the same time, tourists are communicators of urban civilization. They promote the exchange of urban and rural culture and improve the civilization of local residents to some extent. Residents of rural tourism regions should not only engaged in the agricultural tourism, but also learn and promote tourism management and agricultural science and technology, and being familiar with local history and culture and folk customs. In this sense, the promotion of the cultural taste of agricultural tourism will improve peoples quality of science and culture.

\section{Suggestions on promoting the cultural taste of peasant household tourism}

Cultural taste is the new growth of the tourism development at the present stage. It is the essence of the vitality of tourism products, and the core element of creating the difference. The economic value and benefit of peasant household tourism is in proportion to its quality and cultural taste. Enriching the cultural connotation and enhancing the cultural quality of peasant household tourism can make the peasant household tourism vigorous and obtain high added value. It is the key to 
enhance its economic value and tourism value. It is even the source of the sustainable development of farm house enjoyment.

Therefore, to promote the deep development of peasant household tourism, it is vital to enhance the quality and discuss how to enrich the cultural connotation of peasant household tourism and enhance the cultural taste. Specifically, it can be started from the following aspects:

\section{Protect rural ecological environment and make good use of rural resources}

Rural resources and environment is the premise of the development of peasant household tourism, and it is also the necessary condition to support the cultural taste of farm house enjoyment. Hence, to enhance the cultural taste of peasant household tourism, it is initial to establish the scientific concept of tourism development, pay enphasis on the protection of rural ecological environment and make good use of rural resources. The following things must be done:

Firstly, establish a sense of protecting resources, focus on the sustainable development of peasant household tourism, plan and carry out the development of farm house enjoyment.

Secondly, establish quality awareness, take the whole situation of rural development into account, carefully design the development of peasant household tourism in every detail, and strictly forbid the blind development of rural natural resources.

Thirdly, pay emphasis on the coordination of nature and humanity. The construction of buildings of farm house enjoyment cannot blindly imitate buildings in cities. It is supposed to respect the rural cultural traditions, promote rural architectural culture. Buildings with local characteristics should be built.

Fourth, properly handle the rubbish and waste water produced by the development of peasant household tourism, maintain the ecological balance, ensure the countryside' s fresh, pure, and natural, and maintain the long attractiveness of rural environment.

\section{Excavate rural cultural connotations}

Excavating rural cultural connotations is the base of forming the characteristics and enhancing the cultural taste of peasant household tourism. Whether the rural cultural connotations can be displayed or not is the key to decide the success of the development of peasant household tourism. To excavate the rural cultural connotation, we must make adequate investigation and research of the folklore and customs of local countryside, identify advantages and features, and develop tourism cultural products with difference and monopoly. We cannot neglect the actual situation or develop tourism projects mechanically only by blindly imitation.

Based on these, the low level development of making mahjong and chess as the main activities needs to be changed, and specialty products and superior brand should be created to promote the deep development of peasant household tourism. The development of farm house enjoyment is supposed to display the farming culture. Traditional agricultural tools such as the waterwheel, the watermill, and the wheelbarrow can be added into the activities. And tourists can be organized to do some simple farm work. This can delight tourists and make them experience the happiness of agricultural work, and the attractiveness of peasant household tourism can be enhanced.

At the same time, the development of specialty projects such as folk festivals, folk ceremony show and folk art performance can be taken into consideration. On one hand, these specialty projects can bring tourists the feeling of the atmosphere of countryside when they take part in the folk culture. On the other hand, the importance of peasant household tourism to tourists can be enhanced.

\section{Increase the participatory and experiential of tourism activities}

With the improving of people' s living condition and the mature of tourism psychology, people pay more attention to the experience of exotic culture when they travel. Traditional formula cursory tourism cannot meet peoples needs of pursuing the personality. Tourism with strong paticipatory and interactive is increasingly popular.

Thus, the development of peasant household tourism is supposed to according to this trend to 
develop projects with paticipatory and experiential. The development of the project must base on the rural cultural characteristics and avoid being familiar with tourism activities in cities. Projects such as ping-pong, basketball and kara ok had better to be less developed or even not to be developed. Peasant household tourism should develop participatory activities with rural features on basis of rural farming culture and folk culture.

In aspect of experience farming culture, farming projects such as planting trees, plunking and tilling the land can be developed to make tourists have realistic perception of the countryside when they do farm work. And let tourists feel the agricultural society style which is far away from them.

In aspects of experience the rural folk culture, tourists can take part in the folk festival, make folk arts and crafts by themselves and learn to cook farmhouse style diet. These can broaden their horizon and delight them, so that they will prefer peasant household tourism.

\section{improve the service facilities and enhance the service level}

Paying attention to the improvement of the service facilities and service level of tourism is an important part in the increasing of the cultural taste of peasant household tourism. The service facilities of peasant household tourism should reflect the principle of service-oriented. It needs to be coordinated with the rural environment to make it an integral part of the whole environment of the peasant household tourism. The construction of the service facilities should take the rural cultural connotation as the background, the appearance should reflect the characteristics of regional culture, the merge of environment and facilities and the color coordination.

Condition of the facilities can meet the needs of tourists on the scale, have a reasonable layout and with good safety and sanitary condition. It is necessary for peasant household tourism service to implement the idea of human-oriented, and to focus on the humane care of tourists. Attendants need to have the quality of hospitality, the nature of advocating etiquette, higher cultural cultivation, attentive service and customs of clean. Therefore, it is critical to strengthen the training of the cultural knowledge, travel tips and service etiquette and other aspects of the attendants of peasant household tourism, to enhance their sense of service and improve the service level.

Generally speaking, to increase the cultural taste of peasant household tourism, protecting resources and environment is the premise, excavating rural cultural connotations is the key, concentrating on the participatory and experiential of the activities is the focus and the improvement of service facilities and service levels is the insurance. Enhancing the cultural taste of farm house enjoyment should have efforts from many aspects and developments of multi-angle to achieve good

result. And the increase of the cultural taste of peasant household tourism will enhance the development potential of the tourism to promote the sustained and healthy development of China' $\mathrm{s}$ peasant household tourism.

\section{References}

[1] Maria - Victoria Solstrand. Marine angling tourism in N orway and I celand: Finding balance in management policy for sustainability[J]. Nat Resour Forum . 2013 (2)

[2] Carmen Padin. A sustainable tourism planning model: components and relationships[J]. European Business Review . 2012 (6)

[3] Metin Kozak,Drew Martin. Tourism life cycle and sustainability analysis: Profit-focused strategies for mature destinations[J]. Tourism Management . 2011 (1)

[4] Isabel Pilar Albaladejo-Pina,María Teresa Díaz-Delfa. Tourist preferences for rural house stays: Evidence from discrete choice modelling in Spain[J]. Tourism Management . 2009 (6)

[5] Črtomir Rozman,Majda Potočnik,Karmen Pažek,Andreja Borec,Darja Majkovič,Marko Bohanec. A multi-criteria assessment of tourist farm service quality[J]. Tourism Management . 2008 (5) 